\title{
Wpływ środowiska na motywację do wyboru studiów przez studentów rzeszowskich uczelni
}

\section{Impact of the environment on the motivation to choose studies by university students in Rzeszów (Poland)}

Streszczenie: Motywacja jest działaniem człowieka, które zależy od jego środowiska życia. Otoczenie rodziców, rodzeństwa, dziadków, przyjaciół i znajomych kształtuje postrzeganie świata przez dziecko, wpływa na podejmowanie przez nie różnych czynności życiowych, a także implikuje różne motywy kreowania ludzkich zachowań. Celem artykułu było poszerzenie wiedzy na temat znaczenia wpływu środowiska na motywację do wyboru kierunków studiów przez młodzież akademicką z uwzględnieniem podziału ze względu na płeć. Problemem badawczym była deklaracja respondentów w postrzeganiu wpływów: rodziców, tradycji rodzinnych, rówieśników, nauczycieli, mediów, doradcy zawodowego oraz łatwości dostania się na studia na wybór danego kierunku. Założono hipotezę zerową $\left(\mathrm{H}_{0}\right)$, stwierdzającą brak zróżnicowania badanych na poziomie istotności statystycznej według płci. Wykonane obliczenia nie wykazały zróżnicowania na poziomie istotności statystycznej. Wyższe wartości procentowe w zakresie wpływu rodziny, tradycji rodzinnych, nauczycieli, mediów, łatwości dostania się na studia i porad doradcy zawodowego, za wyjątkiem wpływu kolegów, uzyskały kobiety. Badania poszerzyły wiedzę o niewielkim wpływie środowiska szkolnego młodzieży, zwłaszcza doradcy zawodowego, na wybór kierunku studiów. Postuluje się zwiększenie możliwości pomocowych ze strony szkoły, zwłaszcza doradcy zawodowego, w celu zwiększenia świadomości młodzieży w zakresie właściwego doboru ścieżki kształcenia.

\begin{abstract}
Motivation is a human activity that depends on one's living environment. The environment of parents, siblings, grandparents, friends and acquaintances shapes the child's perception of the world, influences their taking various life activities, and also implies various motives for creating human behaviour. The article aimed to broaden the knowledge on the significance of said influence on the motivation to chose the fields of study of academic youth divided by gender. The research problem was the respondents' perception of the influence that parents, family traditions, peers, teachers, media, and career counsellor have when it comes to choosing a field of study, while also taking into account the ease of getting into a given field of study. A null hypothesis $\left(\mathrm{H}_{0}\right)$ was assumed, stating no differentiation of the subjects at the level of statistical significance by gender. The performed calculations did not show any
\end{abstract}


differences at the level of statistical significance. Higher percentages were obtained by women in terms of the influence of family, family traditions, teachers, media, ease of getting into university and career counsellor, except for the influence of acquaintances. The research broadened the knowledge about the small influence of the school environment of young people, especially the vocational counsellor, on the motivation to chose particular fields of study. It is postulated to increase the support possibilities on the part of the school, especially the vocational counsellor, to increase young people's awareness regarding the proper selection of their education path.

Słowa kluczowe: edukacja; doradca; motywacja; praca; rodzina; środowisko

Keywords: counsellor; education; environment; family; motivation; work

Otrzymano: 21 stycznia 2021

Received: 21 January 2021

Zaakceptowano: 24 maja 2021

Accepted: 24 May 2021

\section{Sugerowana cytacja/Suggested citation:}

Chodkowski, Z. (2021). Wpływ środowiska na motywację do wyboru studiów przez studentów rzeszowskich uczelni. Przedsiębiorczość - Edukacja [Entrepreneurship - Education], 17(1), 126-139. https://doi.org/10.24917/20833296.171.10

\section{Wstęp}

Środowisko życia dziecka wpływa na jego rozwój osobisty, zarówno fizyczny, jak i psychospołeczny. Y. Kim i współautorzy twierdzą za U. Bronfenbrennerem (2009), że rodzice odgrywają kluczową rolę w edukacji dzieci jako jeden z wielu wpływów społeczno-kulturowych, który obejmuje również szkołę i społeczność w różnych kontekstach (Kim, Mok, Seidel, 2020).

Autorki: M. Farnicka i H. Liberska (2014) wyjaśniają, że na każdym poziomie edukacji: kulturowym, relacyjnym i operacyjnym, jednostka zdobywa wiedzę i doświadczenie niezbędne do pełnienia ról społecznych, budowania swojej tożsamości i koncepcji własnego życia. W ten sposób na każdym poziomie uruchamianych jest wiele interakcji, które prowadzą do dalszych zmian zarówno w systemie, jak i u poszczególnych jednostek. Rodzina może inspirować dziecko do osiągania dobrych wyników w szkole. Przynależność do całej rodziny zwiększa pewność wykonania zadania i co więcej, zachęca do tworzenia pozytywnego stylu uczenia się w dalszych poszukiwaniach (Mantica, Moneva, Malbas, 2020). Kim i współautorzy (2020), dostrzegają potrzebę zwiększenia psychicznego i behawioralnego zaangażowania rodziców, albowiem to oni mają większy wpływ na dzieci pod względem edukacji i związanych z nią osiągnięć niż poziom Skali Samooceny Rosenberga (Rosenberg Self-Esteem Scale - SES).

J. Nadobnik i jego zespół przeprowadzili badania, podczas których porównali grupę badawczą według płci pod kątem motywacji do podjęcia studiów. Istotność statystyczną wykazały trzy predyktory: konieczność zdobycia wyższego wykształcenia, przeświadczenie, że łatwo jest dostać się na uczelnię oraz przekonanie przez znajomych lub rodzinę (Nadobnik, Tarnowski, Nowak, 2017). Inaczej podeszli do problemu L. Messineo i współautorzy (2019), ponieważ opisali oni rodzaje motywacji do wyboru studiów pielęgniarskich oraz wymienili tradycje rodzinne w zakresie kontynuowania zawodów medycznych w danej rodzinie. 
Reasumując, autorzy w swoich eksploracjach badawczych dostrzegają wagę i wpływ perswazji rodzinnej, tradycji rodzinnych, rówieśników i przyjaciół na wybór kierunku studiów.

\section{Wpływ otoczenia na motywację do podjęcia nauki}

Człowiek ma różną motywację wynikającą z potrzeb biologicznych i psychologicznych. T. Kocowski (1993) definiuje motywację jako całokształt procesów zachodzących w układzie nerwowym człowieka, które przejawiają tendencję lub są z nią sprzeczne. Procesy te wyzwalają i stymulują aktywność, tłumiąc inne tendencje lub sygnalizując satysfakcję lub niezadowolenie ze stopnia zaspokojenia potrzeb lub realizacji zadań. Natomiast zdaniem P.G. Zimbardo i współautorów motywacja to wszystkie procesy, które biorą udział w inicjowaniu, kierowaniu i utrzymywaniu ludzkiej aktywności fizycznej i psychicznej. Motywacja wymaga stymulacji oraz determinuje jedną z możliwych reakcji, które jednostka wyzwala w danej sytuacji. Każda motywacja obejmuje różne procesy umysłowe, które wpływają na nasze działania i dokonywanie różnych wyborów, towarzyszy też wielu zachowaniom ludzkim, które są mniej lub bardziej świadome (Zimbardo, Johnson, McCann, 2010). Z kolei J. Reykowski (1992) mówi o motywacji jako o procesie regulacji psychicznej, dzięki któremu aspiracje kształtują się jako skłonność do podejmowania ukierunkowanych działań dla określonego celu. Działaniom tym można zapobiegać, opóźniać je lub modyfikować. Z drugiej strony, funkcją dążeń jest takie kierowanie ludzkimi działaniami, aby prowadziły one do określonego skutku, zgodnego z intencją.

Procesy motywacyjne mogą stymulować aktywność zewnętrzną - wszystkie czynności ludzkie - a także aktywność wewnętrzną jako czynności umysłowe, w tym procesy umysłowe. Czasami mogą to być nawet działania odruchowe. Dopiero głębsza analiza zachowania może przybliżyć badacza do odkrycia pojedynczego motywu działania (Kocowski, 1993).

Motywacja jest ważnym czynnikiem w procesie edukacji, wzmacniającym osiąganie różnych celów obszaru wiedzy. Zimbardo i inni wskazują na motywację wewnętrzną i zewnętrzną. Motywacja wewnętrzna charakteryzuje się dobrowolnym wykonywaniem danej czynności przez jednostkę z poczuciem przyjemności, a nawet radości. Pochodzi z wnętrza osoby, która angażuje się w działania dla samego działania, również przy braku zewnętrznej nagrody. Ten rodzaj motywacji ma swoje źródło we właściwościach wewnętrznych, np. cechach osobowości lub szczególnych zainteresowaniach (Zimbardo, Johnson, McCann, 2010). Motywacja wewnętrzna to niezależna, autonomiczna wartość, która przynosi jednostce wiele satysfakcji, np. uczniowie o wysokim poziomie tej motywacji odnoszą większe sukcesy w szkole, a także mają większe osiągnięcia. Ponadto mają niski poziom lęku związany ze szkołą, nauczycielami i przedmiotami oraz pozytywnie oceniają własne kompetencje. Te wyniki badań są niezależne od poziomu wykształcenia, płci i grupy etnicznej (Tołwińska, 2009). Natomiast motywacja zewnętrzna obejmuje zachowania ukierunkowane na efekty zewnętrzne, np. uczniowie są zewnętrznie zmotywowani do nauki m.in. przez nagrody, kary, oceny, pochwały związane z ich osiągnięciami lub z powodu przymusu (Zimbardo, Johnson, McCann, 2010). Rozróżnienie to przeciwstawia ludzkie motywy i popędy wynikające ze świadomej motywacji tym motywom i popędom, których źródła tkwią w nieświadomej motywacji, ponieważ zmotywowani ludzie mogą, ale nie muszą, być świadomi popędów lub motywów leżących u podstaw ich zachowania - tak jak pobudzenie 
emocjonalne może pojawiać się świadomie lub na poziomie nieświadomym (Zimbardo, Johnson, McCann, 2010).

Z reguły ludzie kierują się wieloma motywami jednocześnie, których hierarchia ważności jest chwiejna i nie zawsze w pełni realizowana. Dostrzegalne realne potrzeby mieszają się z marzeniami, pozytywne emocje z negatywnymi emocjami, a pewność siebie - z niepewnością (Chodkowski, 2019a: 81).

Rodzina i szkoła wspólnie tworzą tzw. środowisko wychowawcze, w którym jednostki wpływają na rozwój psychiki i kształtowanie osobowości dzieci i młodzieży. Z jednej strony rodzina wpływa na tworzenie określonego systemu wartości (np. rozróżnianie dobra i zła). Natomiast nauczanie i wychowanie w szkole powierzone jest nauczycielowi, który towarzyszy uczniowi w rozwoju (Miciura, 2020).

Farnicka i Liberska (2014: 65-66) wskazują na model szkoły zwany Culturally Relevant Pedagogy (CRP), który zakłada, że edukacja ma znaczący związek ze środowiskiem (Brown-Jeffy, Cooper, 2011) i opiera się na pięciu elementach. Są to:

1. Identyfikacja tożsamości przedmiotów edukacyjnych i ich kulturowo oczekiwanych osiągnięć.

2. Ustalenie zasad rzetelnej oceny i równego dostępu do wiedzy.

3. Uwzględnienie potencjału rozwojowego uczniów, wykorzystanie narzędzi i sposobów pracy adekwatnych do ich rozwoju i potrzeb psychologicznych, np. stylów i technik uczenia się, a także umiejętności związanych z motywowaniem, angażowaniem, współpracą i komunikacją.

4. Filozofia edukacji - jako holistyczne podejście do nauczania „całego dziecka”, wspomagające rozwój i umożliwiające transfer wiedzy poza szkołę, integrujące środowisko szkolne z domowym i lokalnym, np. uznawane kulturowo umiejętności rozwojowe, m.in.: komunikacja interpersonalna, emocje, umiejętność współpracy.

5. Budowanie relacji i atmosfery w szkole i klasie na podstawie otwartości, zaufania i partnerskiego traktowania uczniów i ich rodziców.

Oprócz sprzyjającego środowiska szkolnego istotną rolę w budowaniu silnego kapitału intelektualnego odgrywają również uzdolnienia, kreatywność, cierpliwość i radość.

\section{Metodologia badań własnych}

Przedmiotem niniejszego opracowania jest analiza wpływu środowiska życia studentów kierunków humanistycznych Uniwersytetu Rzeszowskiego oraz studentów kierunków ścisłych Politechniki Rzeszowskiej na motywację do podjęcia przez nich studiów, z uwzględnieniem płci. Celem badania było poszerzenie wiedzy na temat znaczenia wpływu na wybór kierunku studiów przez młodzież akademicką zmiennej niezależnej, którą jest płeć.

W nawiązaniu do tematu eksploracji sformułowano następujący problem badawczy: Który kierunek studiów różnicuje deklaracje badanych studentów Uniwersytetu Rzeszowskiego i Politechniki Rzeszowskiej, podzielonych pod względem płci, w postrzeganiu wpływu: rodziców, tradycji rodzinnych, rówieśników, nauczycieli, mediów, doradcy zawodowego, łatwości dostania się na dany kierunek studiów.

Przyjęto hipotezę zerową $\left(\mathrm{H}_{0}\right)$, stwierdzającą brak zróżnicowania na poziomie istotności statystycznej między kobietami a mężczyznami w zakresie wpływu środowiska (rodziców, tradycji rodzinnych, rówieśników, nauczycieli, mediów, doradcy zawodowego) oraz łatwości dostania się na dany kierunek studiów na motywację do wyboru tego kierunku. 
Badaniami objęto 400 studentów Uniwersytetu Rzeszowskiego i Politechniki Rzeszowskiej. Po weryfikacji ankiet 17 zostało odrzuconych z powodu niekompletnych odpowiedzi. Do kolejnego etapu zakwalifikowano 383 ankiety, w tym 239 studentek i 144 studentów.

Badania przeprowadzono na dwóch uczelniach w IV kwartale 2018 r. metodą sondażu diagnostycznego. Pytania do kwestionariusza ankiety badawczej przygotował autor artykułu, a odpowiedzi skonstruowano na podstawie skali Likerta. W obliczeniach statystycznych wykorzystano test chi-kwadrat Pearsona. Studenci wypełniali ankiety dobrowolnie, bezpłatnie i anonimowo.

Wyniki badań

W tabeli 1 przedstawiono płeć respondentów według podziału na uczelnie. Na obu uczelniach zdecydowanie dominowały kobiety, które stanowiły średnio 62,45\% ogółu badanych.

Tabela 1. Rozkład płci respondentów według uczelni

\begin{tabular}{|l|c|c|c|c|c|c|}
\hline \multirow{2}{*}{ Uniwersytet } & \multicolumn{7}{|c|}{ Płeć respondentów } \\
\cline { 2 - 7 } & Kobiety & \% & Mężczyźni & \% & Razem & \% \\
\hline Uniwersytet Rzeszowski & 120 & 63,2 & 70 & 36,8 & 190 & 100 \\
\hline Politechnika Rzeszowska & 119 & 61,7 & 74 & 38,3 & 193 & 100 \\
\hline
\end{tabular}

Źródło: opracowanie własne

Wybór ścieżki życia według J. Poleszczuka (2017) zależy nie tylko od własnych preferencji, ambicji, umiejętności, wiedzy i informacji, ale także od środowiska, w którym żyjemy. Autor ten podkreśla, że duży wpływ na dokonywane wybory mają rodzice, nauczyciele i koledzy. Na podstawie badań własnych przeprowadzonych przez autora niniejszego artykułu w 2016 r. nad motywami wyboru kierunku studiów pedagogicznych stwierdzono, że istotnym czynnikiem w tym zakresie był wpływ środowiska rodzinnego, szkolnego i uniwersyteckiego (Chodkowski, 2019c).

W tabeli 2 przedstawiono wpływ rodziców na motywację wyboru studiów z uwzględnieniem płci ankietowanych, w badaniach przeprowadzonych w $2018 \mathrm{r}$.

Opierając się na wynikach badań przedstawionych w tabeli 2, można stwierdzić, że respondenci z obu grup najczęściej wskazali czynniki, które były zupełnie nieistotne 37,7\% dla kobiet i 41,0\% dla mężczyzn. Drugie miejsce zajęły wartości czynników mało ważnych: 23,4\% i 25,7\%. Jednak decydujące czynniki o wpływie rodziców na motywację do wyboru kierunku studiów ukształtowały się na poziomie 5,0\% i 8,3\%. Należy zauważyć, że zsumowane wartości czynników, które w różnym stopniu wpływały na motywację do wyboru studiów, wyniosły: dla kobiet 38,9\%, a dla mężczyzn - 33,4\%. Można więc stwierdzić, że rodzice mają duży wpływ na dalszą edukację swoich dzieci, choć częściowo przejawia się to na różnych poziomach wyboru, a suma trzech czynników, które zadecydowały o wpływie wyboru studiów, jest nieznacznie większa dla kobiet - 38,9\% niż dla mężczyzn - 33,4\%. Można zatem wnioskować, że kobiety są bardziej podatne na wpływ rodziców na wybór dalszego etapu edukacji w przeciwieństwie do mężczyzn. 
Tabela 2. Rodzice a motywacja wyboru studiów według płci respondentów

\begin{tabular}{|c|c|c|c|c|c|c|c|c|}
\hline \multirow[b]{2}{*}{$\begin{array}{l}\text { Wpływ rodziców } \\
\text { na motywację } \\
\text { wyboru studiów }\end{array}$} & \multicolumn{2}{|c|}{ Kobiety } & \multicolumn{2}{|c|}{ Mężczyźni } & \multicolumn{4}{|c|}{ Chi-kwadrat } \\
\hline & $\begin{array}{l}\text { ते } \\
\text { Z }\end{array}$ & $100 \%$ & $\begin{array}{l}\underset{J}{J} \\
\text { Z }\end{array}$ & $100 \%$ & & Wartość & df & $\mathbf{p}$ \\
\hline \multirow{2}{*}{$\begin{array}{l}\text { 1. Czynniki, } \\
\text { które były } \\
\text { dla Ciebie } \\
\text { zupełnie bez } \\
\text { znaczenia } \\
\end{array}$} & \multirow[b]{2}{*}{90} & \multirow[b]{2}{*}{37,7} & \multirow[b]{2}{*}{59} & \multirow[b]{2}{*}{41,0} & $\begin{array}{c}\text { Chi-kwadrat } \\
\text { Pearsona }\end{array}$ & 5,080 & 4 & 0,279 \\
\hline & & & & & $\begin{array}{c}\text { Iloraz } \\
\text { wiarygodności }\end{array}$ & 5,187 & 4 & 0,269 \\
\hline \multirow[b]{2}{*}{$\begin{array}{l}\text { 2. Czynniki, } \\
\text { które były } \\
\text { dla Ciebie } \\
\text { mało ważne, } \\
\text { ale jednak je } \\
\text { dostrzegałeś, } \\
\text { brałeś pod } \\
\text { uwagę }\end{array}$} & \multirow[b]{2}{*}{56} & \multirow[b]{2}{*}{23,4} & \multirow[b]{2}{*}{37} & \multirow[b]{2}{*}{25,7} & \multicolumn{4}{|c|}{ Miary sumaryczne } \\
\hline & & & & & Nominalna & Wartość & \multicolumn{2}{|c|}{$\begin{array}{c}\text { Istotność } \\
\text { przybliżona }\end{array}$} \\
\hline $\begin{array}{l}\text { 3. Czynniki, } \\
\text { które były } \\
\text { średnio ważne }\end{array}$ & 54 & 22,6 & 27 & 18,8 & Phi & 0,115 & \multicolumn{2}{|c|}{0,279} \\
\hline $\begin{array}{l}\text { 4. Czynniki, } \\
\text { które były } \\
\text { ważne, ale } \\
\text { niedecydujące }\end{array}$ & 27 & 11,3 & 9 & 6,3 & V Kramera & 0,115 & \multicolumn{2}{|c|}{0,279} \\
\hline $\begin{array}{l}\text { 5. Czynniki, } \\
\text { które były } \\
\text { decydujące }\end{array}$ & 12 & 5,0 & 12 & 8,3 & $\begin{array}{l}\text { Współczynnik } \\
\text { kontyngencji }\end{array}$ & 0,114 & \multicolumn{2}{|c|}{0,279} \\
\hline
\end{tabular}

Źródło: opracowanie własne

Tabela 3. Tradycje rodzinne a motywacja wyboru kierunku studiów przez badanych respondentów według płci

\begin{tabular}{|c|c|c|c|c|c|c|c|c|}
\hline \multirow{2}{*}{$\begin{array}{l}\text { Wpływ tradycji } \\
\text { rodzinnych } \\
\text { na motywację } \\
\text { wyboru studiów }\end{array}$} & \multicolumn{2}{|c|}{ Kobiety } & \multicolumn{2}{|c|}{ Mężczyźni } & \multicolumn{4}{|c|}{ Chi-kwadrat } \\
\hline & $\begin{array}{l}\text { ஸे } \\
\text { II } \\
Z\end{array}$ & $100 \%$ & $\begin{array}{l}\underset{Z}{J} \\
\mathrm{z}\end{array}$ & $100 \%$ & & Wartość & df & $\mathbf{p}$ \\
\hline \multirow{2}{*}{$\begin{array}{l}\text { 1. Czynniki, } \\
\text { które były } \\
\text { dla Ciebie } \\
\text { zupełnie bez } \\
\text { znaczenia }\end{array}$} & \multirow{2}{*}{198} & \multirow{2}{*}{82,8} & \multirow[b]{2}{*}{112} & \multirow{2}{*}{77,8} & $\begin{array}{c}\text { Chi-kwadrat } \\
\text { Pearsona }\end{array}$ & 5,099 & 4 & 0,277 \\
\hline & & & & & $\begin{array}{c}\text { Iloraz } \\
\text { wiarygodności }\end{array}$ & 5,112 & 4 & 0,276 \\
\hline \multirow[b]{2}{*}{$\begin{array}{l}\text { 2. Czynniki, } \\
\text { które były } \\
\text { dla Ciebie } \\
\text { mało ważne, } \\
\text { ale jednak je } \\
\text { dostrzegałeś, } \\
\text { brałeś pod } \\
\text { uwage }\end{array}$} & \multirow[b]{2}{*}{14} & \multirow[b]{2}{*}{5,9} & \multirow[b]{2}{*}{16} & \multirow[b]{2}{*}{11,1} & \multicolumn{4}{|c|}{ Miary sumaryczne } \\
\hline & & & & & Nominalna & Wartość & \multicolumn{2}{|c|}{$\begin{array}{c}\text { Istotność } \\
\text { przybliżona }\end{array}$} \\
\hline
\end{tabular}




\begin{tabular}{|l|c|c|c|c|c|c|c|}
\hline $\begin{array}{l}\text { 3. Czynniki, } \\
\text { które były } \\
\text { średnio ważne }\end{array}$ & 15 & 6,3 & 11 & 7,6 & Phi & 0,115 & 0,277 \\
\hline $\begin{array}{l}\text { 4. Czynniki, } \\
\text { które były } \\
\text { ważne, ale } \\
\text { niedecydujące }\end{array}$ & 8 & 3,3 & 2 & 1,4 & V Kramera & 0,115 & 0,277 \\
\hline $\begin{array}{c}\text { 5. Czynniki, } \\
\text { które były } \\
\text { decydujące }\end{array}$ & 4 & 1,7 & 3 & 2,1 & $\begin{array}{c}\text { Współczynnik } \\
\text { kontyngencji }\end{array}$ & 0,115 & 0,277 \\
\hline
\end{tabular}

Źródło: opracowanie własne

Wyniki badań przedstawione w tabeli 3 pokazują, że wartości czynników zupełnie nieistotnych dla wpływu tradycji rodzinnych na wybór kierunku studiów wynoszą 82,8\% dla kobiet i 77,8\% dla mężczyzn. W przeciwieństwie do tego wartości czynników decydujących o motywacji do wyboru kierunku studiów wynoszą odpowiednio dla kobiet 1,7\% i dla mężczyzn - 2,1\%. Wynika $\mathrm{z}$ tego, że respondenci nie identyfikują się z rodzinnymi tradycjami w zakresie wyboru kierunku studiów i kariery zawodowej. Nawet jeśli widzą jakieś powiązania, to chcą rozwijać się zawodowo według własnego pomysłu i spróbować swoich sił w innym zakresie wykonywania pracy niż ich rodzice.

Tabela 4. Koledzy a motywacja wyboru kierunku studiów według płci respondentów

\begin{tabular}{|c|c|c|c|c|c|c|c|}
\hline \multirow[b]{2}{*}{$\begin{array}{l}\text { Wpływ kolegów } \\
\text { na motywację } \\
\text { wyboru studiów }\end{array}$} & \multicolumn{2}{|c|}{ Kobiety } & \multicolumn{2}{|c|}{ Mężczyźni } & \multicolumn{3}{|c|}{ Chi-kwadrat } \\
\hline & $\begin{array}{l}\text { तે } \\
\text { II } \\
Z\end{array}$ & $100 \%$ & $\begin{array}{l}\underset{J}{J} \\
\text { II } \\
Z\end{array}$ & $100 \%$ & & Wartość & df \\
\hline \multirow{2}{*}{$\begin{array}{l}\text { 1. Czynniki, } \\
\text { które były } \\
\text { dla Ciebie } \\
\text { zupełnie bez } \\
\text { znaczenia } \\
\end{array}$} & \multirow[b]{2}{*}{175} & \multirow[b]{2}{*}{73,2} & \multirow[b]{2}{*}{103} & \multirow[b]{2}{*}{71,5} & $\begin{array}{c}\text { Chi-kwadrat } \\
\text { Pearsona } \\
\end{array}$ & 6,083 & 0,193 \\
\hline & & & & & $\begin{array}{c}\text { Iloraz } \\
\text { wiarygodności }\end{array}$ & 5,889 & 0,208 \\
\hline \multirow[b]{2}{*}{$\begin{array}{l}\text { 2. Czynniki, } \\
\text { które były } \\
\text { dla Ciebie } \\
\text { mało ważne, } \\
\text { ale jednak je } \\
\text { dostrzegałeś, } \\
\text { brałeś pod } \\
\text { uwagę }\end{array}$} & \multirow[b]{2}{*}{36} & \multirow[b]{2}{*}{15,1} & \multirow[b]{2}{*}{20} & \multirow[b]{2}{*}{13,9} & \multicolumn{3}{|c|}{ Miary sumaryczne } \\
\hline & & & & & Nominalna & Wartość & $\begin{array}{c}\text { Istotność } \\
\text { przybliżona }\end{array}$ \\
\hline $\begin{array}{l}\text { 3. Czynniki, } \\
\text { które były } \\
\text { średnio ważne }\end{array}$ & 23 & 9,6 & 11 & 7,6 & Phi & 0,126 & 0,193 \\
\hline $\begin{array}{l}\text { 4. Czynniki, } \\
\text { które były } \\
\text { ważne, ale } \\
\text { niedecydujące }\end{array}$ & 4 & 1,7 & 7 & 4,9 & V Kramera & 0,126 & 0,193 \\
\hline $\begin{array}{l}\text { 5. Czynniki, } \\
\text { które były } \\
\text { decydujące }\end{array}$ & 1 & 0,4 & 3 & 2,1 & $\begin{array}{l}\text { Współczynnik } \\
\text { kontyngencji }\end{array}$ & 0,125 & 0,193 \\
\hline
\end{tabular}

Źródło: opracowanie własne 
Jak pisze Poleszczuk (2017), uczniowie aktywnie uczestniczą i funkcjonują w różnych grupach rówieśniczych. Nawiązują bliższe lub dalsze relacje międzyludzkie, które są związane $\mathrm{z}$ określoną rolą i pozycją $\mathrm{w}$ danej grupie. $\mathrm{W}$ ten sposób środowisko szkolne tworzy złożony i dynamiczny system.

Według danych z tabeli 4, wpływ kolegów okazał się nieistotny dla wyboru kierunku studiów przez ankietowanych. Najwyższe wartości uzyskano dla czynników zupełnie nieistotnych: 73,2\% dla kobiet i 71,5\% dla mężczyzn. Dla decydujących czynników odpowiedzi wyniosły odpowiednio $0,4 \%$ i $2,1 \%$.

Należy założyć, że ludzie w naszym otoczeniu wpływają na motywy naszego działania w mniejszym lub większym stopniu - to zależy od naszej świadomości. Jednak w tym przypadku wpływ kolegów na wybór kierunku studiów nie był znaczący i dotyczył jedynie 0,4-2,1\% respondentów.

Tabela 5. Nauczyciele a motywacja wyboru kierunku studiów według płci

\begin{tabular}{|c|c|c|c|c|c|c|c|c|}
\hline \multirow{2}{*}{$\begin{array}{c}\text { Wpływ } \\
\text { nauczycieli } \\
\text { na motywację } \\
\text { wyboru studiów }\end{array}$} & \multicolumn{2}{|c|}{ Kobiety } & \multicolumn{2}{|c|}{ Mężczyźni } & \multicolumn{4}{|c|}{ Chi-kwadrat } \\
\hline & $\begin{array}{l}\text { ָे } \\
\text { II } \\
\mathrm{Z}\end{array}$ & $\%$ & $\begin{array}{l}\underset{J}{J} \\
\text { Z }\end{array}$ & $\%$ & & Wartość & df & $\mathbf{p}$ \\
\hline \multirow{2}{*}{$\begin{array}{l}\text { 1. Czynniki, } \\
\text { które były } \\
\text { dla Ciebie } \\
\text { zupełnie bez } \\
\text { znaczenia }\end{array}$} & \multirow{2}{*}{151} & \multirow{2}{*}{63,2} & \multirow{2}{*}{92} & \multirow{2}{*}{63,9} & $\begin{array}{c}\text { Chi-kwadrat } \\
\text { Pearsona }\end{array}$ & 3,069 & 4 & 0,546 \\
\hline & & & & & $\begin{array}{c}\text { Iloraz } \\
\text { wiarygodności }\end{array}$ & 3,063 & 4 & 0,547 \\
\hline \multirow[b]{2}{*}{$\begin{array}{l}\text { 2. Czynniki, } \\
\text { które były } \\
\text { dla Ciebie } \\
\text { mało ważne, } \\
\text { ale jednak je } \\
\text { dostrzegałeś, } \\
\text { brałeś pod } \\
\text { uwagę }\end{array}$} & \multirow[b]{2}{*}{36} & \multirow[b]{2}{*}{15,1} & \multirow[b]{2}{*}{26} & \multirow[b]{2}{*}{18,1} & \multicolumn{4}{|c|}{ Miary sumaryczne } \\
\hline & & & & & Nominalna & Wartość & \multicolumn{2}{|c|}{$\begin{array}{l}\text { Istotność } \\
\text { przybliżona }\end{array}$} \\
\hline $\begin{array}{l}\text { 3. Czynniki, } \\
\text { które były } \\
\text { średnio ważne }\end{array}$ & 31 & 13 & 13 & 9 & Phi & 0,090 & \multicolumn{2}{|c|}{0,546} \\
\hline $\begin{array}{l}\text { 4. Czynniki, } \\
\text { które były } \\
\text { ważne, ale } \\
\text { niedecydujące }\end{array}$ & 18 & 7,5 & 9 & 6,3 & V Kramera & 0,090 & \multicolumn{2}{|c|}{0,546} \\
\hline $\begin{array}{l}\text { 5. Czynniki, } \\
\text { które były } \\
\text { decydujące }\end{array}$ & 3 & 1,3 & 4 & 2,8 & $\begin{array}{l}\text { Współczynnik } \\
\text { kontyngencji }\end{array}$ & 0,089 & \multicolumn{2}{|c|}{0,546} \\
\hline
\end{tabular}

Źródło: opracowanie własne

Uczniowie funkcjonują w systemie szkolnym, w którym nauczyciel jest dla swoich uczniów wzorem do naśladowania i pełni funkcję inicjatora, a także przewodnika wspomagającego ucznia w poznawczym przetwarzaniu informacji i konstruowaniu osobistych struktur wiedzy. Często nauczyciel inspiruje ucznia, a także kontroluje i ocenia pod kątem kolejnej ścieżki edukacyjnej (Nowak, 2015: 67). 
Na podstawie danych zawartych w tabeli 5 można wskazać, że odpowiedzi respondentów z dwóch grup uzyskały zbliżone wartości: 63,2\% i 63,9\%, przy czym czynniki nie miały większego wpływu na wybór uczelni i studiów. Z kolei małe wartości: 1,3\% i 2,8\% dotyczyły tych czynników, które zadecydowały o wyborze studiów. Wynika z tego, że nauczyciel nie odegrał w tym zakresie znaczącej roli, a w wielu przypadkach też nie przyciągał uczniów do swojego przedmiotu, nie zachęcał ich do jego wyboru, nie mobilizował ich i nie wspierał.

Tabela 6. Łatwość dostania się na studia a motywacja do wyboru studiów według płci respondentów

\begin{tabular}{|c|c|c|c|c|c|c|c|c|}
\hline \multirow[b]{2}{*}{$\begin{array}{l}\text { Latwość dostania } \\
\text { się na studia } \\
\text { a motywacja do } \\
\text { wyboru studiów }\end{array}$} & \multicolumn{2}{|c|}{ Kobiety } & \multicolumn{2}{|c|}{ Mężczyźni } & \multicolumn{4}{|c|}{ Chi-kwadrat } \\
\hline & $\begin{array}{l}\text { ले } \\
\text { II } \\
\text { Z }\end{array}$ & $100 \%$ & $\begin{array}{l}\underset{J}{J} \\
\stackrel{I}{Z} \\
\mathrm{z}\end{array}$ & $100 \%$ & & Wartość & df & $\mathbf{p}$ \\
\hline \multirow{2}{*}{$\begin{array}{l}\text { 1. Źródło: } \\
\text { opracowanie } \\
\text { własne. } \\
\text { Czynniki, } \\
\text { które były } \\
\text { dla Ciebie } \\
\text { zupełnie bez } \\
\text { znaczenia }\end{array}$} & \multirow[b]{2}{*}{52} & \multirow[b]{2}{*}{21,8} & \multirow[b]{2}{*}{31} & \multirow[b]{2}{*}{21,5} & $\begin{array}{c}\text { Chi-kwadrat } \\
\text { Pearsona }\end{array}$ & 4,358 & 4 & 0,36 \\
\hline & & & & & $\begin{array}{c}\text { Iloraz } \\
\text { wiarygodności }\end{array}$ & 4,326 & 4 & 0,36 \\
\hline \multirow[b]{2}{*}{$\begin{array}{l}\text { 2. Czynniki, } \\
\text { które były } \\
\text { dla Ciebie } \\
\text { mało ważne, } \\
\text { ale jednak je } \\
\text { dostrzegałeś, } \\
\text { brałeś pod } \\
\text { uwagę }\end{array}$} & \multirow[b]{2}{*}{41} & \multirow[b]{2}{*}{17,2} & \multirow[b]{2}{*}{36} & \multirow[b]{2}{*}{25} & \multicolumn{4}{|c|}{ Miary sumaryczne } \\
\hline & & & & & Nominalna & Wartość & \multicolumn{2}{|c|}{$\begin{array}{c}\text { Istotność } \\
\text { przybliżona }\end{array}$} \\
\hline $\begin{array}{l}\text { 3. Czynniki, } \\
\text { które były } \\
\text { średnio ważne }\end{array}$ & 69 & 28,9 & 32 & 22,2 & Phi & 0,107 & \multicolumn{2}{|l|}{0,360} \\
\hline $\begin{array}{l}\text { 4. Czynniki, } \\
\text { które były } \\
\text { ważne, ale } \\
\text { niedecydujące }\end{array}$ & 46 & 19,2 & 28 & 19,4 & V Kramera & 0,107 & \multicolumn{2}{|l|}{0,360} \\
\hline $\begin{array}{l}\text { 5. Czynniki, } \\
\text { które były } \\
\text { decydujące }\end{array}$ & 31 & 13 & 17 & 11,8 & $\begin{array}{l}\text { Współczynnik } \\
\text { kontyngencji }\end{array}$ & 0,106 & \multicolumn{2}{|l|}{0,360} \\
\hline
\end{tabular}

Źródło: opracowanie własne

Niż demograficzny jest widoczny na polskich uczelniach już od kilku lat. Uczelnie przygotowują różne oferty, aby przyciągnąć młodych ludzi zainteresowanych studiowaniem. Do najczęstszych ułatwień należą m.in.: łatwe dostanie się na studia, pomoc socjalna, internat, staże zagraniczne, staże specjalne czy nawet możliwość zatrudnienia po ukończeniu niektórych kierunków. 
Analizując wyniki przedstawione w tabeli 6, można zauważyć, że najwyższe wartości uzyskano dla czynników o średnim znaczeniu dla kobiet - 28,9\% i 22,2\% dla mężczyzn. Po zsumowaniu trzech czynników ułatwiających wejście na uniwersytet wartości te wyniosły $61,1 \%$ dla kobiet i 53,4\% dla mężczyzn. Łatwość rozpoczynania studiów jest więc ważną ofertą ze strony uczelni, mającą widoczny wpływ na wybór przez młodych ludzi kierunku studiów. W tym badaniu delikatna przewaga, w wysokości paru procent, uwidoczniła się po stronie kobiet.

Tabela 7. Media a motywacja wyboru studiów według płci respondentów

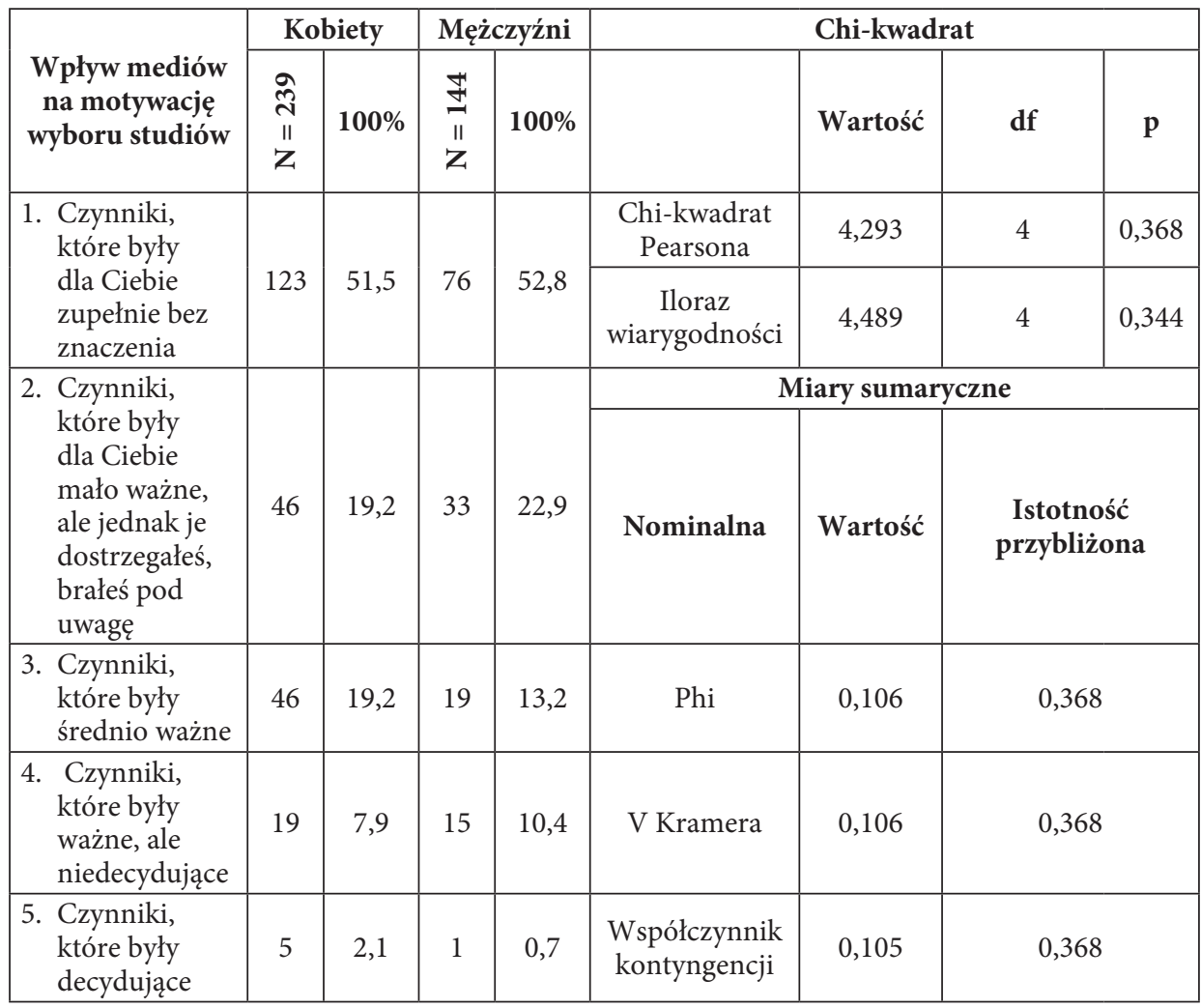

Źródło: opracowanie własne

Media są potężnym źródłem wszelkich informacji, także tych z zakresu studiów zawodowych. Coraz więcej wiadomości pojawia się na stronach internetowych, które dotyczą rynku pracy, zawodów, zapotrzebowania na kwalifikacje, wysokości wynagrodzeń itp. W tym obszarze aktywne są również uczelnie, prezentując ofertę studiów wraz z możliwością zakwaterowania i wsparcia ekonomicznego. Ponadto szkoły wyższe czasami oferują również staże zagraniczne, a nawet zatrudnienie po ukończeniu studiów.

W kolejnym badaniu wpływu mediów na motywację wyboru szkoły wyższej odsetki czynników, które nie wpłynęły na decyzję o wyborze uczelni, kształtowały się na podobnym poziomie - 51,5\% dla kobiet i 52,8\% dla mężczyzn. Z drugiej strony, wartości czynników decydujących były znikome i wynosiły odpowiednio 2,1\% dla kobiet i 0,7\% dla mężczyzn. 
Można stwierdzić, że młodzi ludzie, wybierając studia, nie kierowali się głównie przekazem medialnym. Należy jednak zaznaczyć, że suma trzech czynników o różnej sile ukształtowała się na poziomie $29,2 \%$ dla kobiet i $24,3 \%$ dla mężczyzn, a więc stanowiła prawie 30\% w obszarze dotyczącym podejmowanych decyzji.

Potwierdziła się zatem zasada, że media wywierają potężny wpływ na naszą podświadomość, która jest odtwarzana na wiele różnych sposobów, przez co może mieć czasami znaczący wpływ na podejmowanie decyzji.

Tabela 8. Doradca zawodowy a motywacja do wyboru studiów według płci respondentów

\begin{tabular}{|c|c|c|c|c|c|c|c|c|}
\hline \multirow{2}{*}{$\begin{array}{l}\text { Wpływ doradcy } \\
\text { zawodowego } \\
\text { na motywację } \\
\text { wyboru studiów }\end{array}$} & \multicolumn{2}{|c|}{ Kobiety } & \multicolumn{2}{|c|}{ Mężczyźni } & \multicolumn{4}{|c|}{ Chi-kwadrat } \\
\hline & $\begin{array}{l}\text { ָे } \\
\text { II }\end{array}$ & $100 \%$ & $\begin{array}{l}\underset{Z}{J} \\
\mathrm{Z}\end{array}$ & $100 \%$ & & Wartość & df & $\mathbf{p}$ \\
\hline \multirow{2}{*}{$\begin{array}{l}\text { 1. Czynniki, } \\
\text { które były } \\
\text { dla Ciebie } \\
\text { zupełnie bez } \\
\text { znaczenia }\end{array}$} & \multirow[b]{2}{*}{201} & \multirow[b]{2}{*}{84,1} & \multirow[b]{2}{*}{124} & \multirow[b]{2}{*}{86,1} & $\begin{array}{c}\text { Chi-kwadrat } \\
\text { Pearsona }\end{array}$ & 0,478 & 4 & 0,976 \\
\hline & & & & & $\begin{array}{c}\text { Iloraz } \\
\text { wiarygodności }\end{array}$ & 0,487 & 4 & 0,975 \\
\hline \multirow[b]{2}{*}{$\begin{array}{l}\text { 2. Czynniki, } \\
\text { które były } \\
\text { dla Ciebie } \\
\text { mało ważne, } \\
\text { ale jednak je } \\
\text { dostrzegałeś, } \\
\text { brałeś pod } \\
\text { uwagę }\end{array}$} & \multirow[b]{2}{*}{21} & \multirow[b]{2}{*}{8,8} & \multirow[b]{2}{*}{10} & \multirow[b]{2}{*}{6,9} & \multicolumn{4}{|c|}{ Miary sumaryczne } \\
\hline & & & & & Nominalna & Wartość & \multicolumn{2}{|c|}{$\begin{array}{c}\text { Istotność } \\
\text { przybliżona }\end{array}$} \\
\hline $\begin{array}{l}\text { 3. Czynniki, } \\
\text { które były } \\
\text { średnio ważne }\end{array}$ & 10 & 4,2 & 6 & 4,2 & Phi & 0,035 & \multicolumn{2}{|c|}{0,976} \\
\hline $\begin{array}{l}\text { 4. Czynniki, } \\
\text { które były } \\
\text { ważne, ale } \\
\text { niedecydujące }\end{array}$ & 4 & 1,7 & 2 & 1,4 & V Kramera & 0,035 & \multicolumn{2}{|c|}{0,976} \\
\hline $\begin{array}{l}\text { 5. Czynniki, } \\
\text { które były } \\
\text { decydujące }\end{array}$ & 3 & 1,3 & 2 & 1,4 & $\begin{array}{l}\text { Współczynnik } \\
\text { kontyngencji }\end{array}$ & 0,035 & \multicolumn{2}{|c|}{0,976} \\
\hline
\end{tabular}

Źródło: opracowanie własne

Na podstawie wyników badań zawartych w tabeli 8 można stwierdzić, że ponad $84 \%$ respondentów z obu grup wybrało opcję, w której wpływ doradcy zawodowego na wybór kierunku studiów nie był istotny. Z drugiej strony niewiele, bo 1,3-1,4\% uczniów rozważało pomoc doradcy w wyborze dalszej edukacji. Wyniki tego badania wskazują, że młodzi ludzie mają niską świadomość roli doradcy zawodowego w rozwoju osobistym i zawodowym. Prawdopodobnie problem zostanie nieco zminimalizowany w najbliższych latach dzięki Rozporządzeniu Ministra Edukacji Narodowej z dnia 16 sierpnia 2018 r. w sprawie poradnictwa zawodowego, które weszło w życie z dniem 1 września 2018 r. Rozporządzenie to określa treść programu, warunki, sposób realizacji i organizację poradnictwa zawodowego w szkołach i placówkach. Treść programu obejmuje cztery 
obszary tematyczne: poznanie siebie, świata zawodów i rynku pracy, rynku edukacyjnego i uczenia się przez całe życie, a także planowanie własnego rozwoju oraz podejmowanie decyzji edukacyjnych i zawodowych (Dz.U. 2018, poz. 1675, zał. 1). Wprowadzenie poradnictwa zawodowego do obowiązku szkolnego na wszystkich etapach edukacji podstawowej i średniej stwarza szansę na zmianę wizerunku doradcy zawodowego w zakresie jego pomocy w rozwoju i planowaniu edukacji oraz kariery zawodowej.

\section{Zakończenie}

W podsumowaniu badań przedstawionych w niniejszym artykule należy zauważyć, że zdecydowaną większość respondentów stanowiły kobiety. Respondenci wskazywali na różny stopień wpływu środowiska rodzinnego i szkolnego na motywację do podjęcia studiów według przygotowanych pytań opartych na skali Likerta.

Na podstawie obliczeń statystycznych chi-kwadrat wykazano, że nie ma różnic na poziomie istotności statystycznej między kobietami a mężczyznami (p > 0,05). Dlatego tė̇ pozostawiono hipotezę zerową.

Można jednak zauważyć niewielkie różnice tylko w wartościach procentowych w zakresie postrzegania wpływu na motywację studentów ze względu na płeć na Uniwersytecie Rzeszowskim i Politechnice Rzeszowskiej w następujących obszarach:

- środowisko rodzinne: rodzice, tradycje rodzinne,

- środowisko szkolne: koledzy, nauczyciele, doradca zawodowy,

- środowisko uczelni: media, łatwość dostania się na niektóre kierunki studiów.

Analizując szerzej wartości procentowe, niewielki wpływ na motywację wyboru studiów mają czynniki, które były zupełnie nieistotne. Dotyczą one m.in.: doradcy zawodowego (84,1\% kobiet, $86,1 \%$ mężczyzn), tradycji rodzinnych $(82,8 \%$ kobiet, $77,8 \%$ mężczyzn), kolegów (73,2\% kobiet, 71,5\% mężczyzn), nauczycieli (63,2\% kobiet, 63,9\% mężczyzn) i media (51,5\% kobiet, 52,8\% mężczyzn). W tym przedziale tylko dwa badania uzyskały najniższe wartości procentowe: wpływ rodziców (37,7\% dla kobiet, 41,0\% dla mężczyzn) i łatwość dostania się na studia (21,8\% - kobiety i 21,5\% - mężczyźni). Oznacza to, że zarówno łatwość rozpoczęcia studiów, jak i zdanie rodziców były istotnymi motywami do podjęcia studiów dla badanych studentów.

Biorąc pod uwagę sumę trzech opcji odpowiedzi „tak” (z różnymi poziomami), wyższe odsetki uzyskały kobiety w badaniach dotyczących wpływu: rodziny, tradycji rodzinnych, nauczycieli, mediów, łatwości dostania się na studia i doradcy zawodowego. Największą różnicę w odsetkach uzyskały kobiety w badaniu opisanym w tabeli 6, które dotyczyło łatwości dostania się na studia, bowiem wyniosła ona 61,1\% (a dla mężczyzn - 53,4\%). Z drugiej strony mężczyźni uzyskali przewagę tylko w jednym badaniu dotyczącym wpływu kolegów na motywy wyboru studiów.

Wśród ofert uczelni wyższych „łatwość dostania się na studia” i „rodzina” są ważne dla studentów obojga płci i wpływają na motywację do wyboru kierunku studiów w szerokim zakresie.

Niepokojące może być to, że studenci nie potrzebowali konsultacji z doradcą zawodowym (ponad 80\% wyborów). Prawdopodobnie chcieli rozwijać umiejętności zawodowe zgodnie z własnymi potrzebami i wyborami, choć nie zawsze były one prawidłowe. Dążyli również do realizacji indywidualnych celów, które stawiali sobie według własnego pomysłu i opracowania, bez żadnej pomocy i wsparcia w zakresie poradnictwa zawodowego. Nie zawsze taki wybór jest słuszny i prowadzi do sukcesu w kolejnych etapach życia 
jednostki. Może okazać się, że w krótkim czasie pojawi się frustracja i brak motywacji do następnych aktywności (Chodkowski, 2019b).

Reasumując, na wybór kierunku studiów wpływ ma zarówno środowisko szkolne, jak i rodzinne. Motywacją są również własne zainteresowania, uzdolnienia oraz plany zawodowe tworzone przez pryzmat wysokiego bezrobocia, zwłaszcza na terenach wiejskich i w małych miastach. Powoduje to przymus migracji do aglomeracji, takich jak Kraków, Wrocław i Warszawa, bądź za granicę. Tendencja taka jest bardzo niekorzystna dla wielu obszarów, nie tylko górskich, ale także dla małych miejscowości, czy nawet średniej wielkości miast (Przemyśl, Tarnobrzeg) województwa podkarpackiego, w których notuje się proces systematycznego wyludniania się społeczności lokalnej (Janik, 2019).

Wyniki badań poszerzają wiedzę o wpływie środowiska młodzieży na motywację wyboru kierunków studiów. Istnieje pewna spójność między domem rodzinnym a środowiskiem szkolnym (nauczyciele, rówieśnicy). Nie bez znaczenia jest też wizerunek uczelni w mediach, a także ich oferta dająca duże możliwości rozwoju edukacyjnego i prozawodowego. Nieco gorzej wypada znaczenie doradcy zawodowego, który wciąż jest niedoceniany przez uczniów szkół podstawowych, średnich, a także wyższych.

Wskazane jest przeprowadzenie podobnych badań w celu dalszej diagnozy prozawodowych postaw młodych ludzi (nie tylko studentów) w zakresie wpływu środowiska na motywację do wyboru kierunku studiów i związanych z nimi planów zawodowych. Wyniki badań mogą być wykorzystywane przez doradców zawodowych i szkolnych, a także nauczycieli i rodziców. Poznanie motywacji uczniów może być również pomocne w tworzeniu nowych programów edukacyjnych, lepiej dostosowanych do potrzeb zmieniającego się rynku pracy.

\section{Literatura}

References

Bronfenbrenner, U. (2009). The ecology of human development: Experiments by Nature and design. Harvard University Press: Cambridge.

Brown-Jeffy, S., Cooper, J.E. (2011). Toward A Conceptual Framework Of Culturally Relevant Pedagogy. Teacher Education Quarterly, 38(1), 65-84.

Chodkowski, Z. (2019a). Adaptacja człowieka do środowiska pracy. Rzeszów: Wydawnictwo Uniwersytetu Rzeszowskiego.

Chodkowski, Z. (2019b). Autoocena własnych szans funkcjonowania zawodowego po ukończeniu studiów pedagogicznych. Szkoła - Zawód - Praca, 17, 201-216. doi: 10.34767/SZP.2019.01.14

Chodkowski, Z. (2019c). Plany zawodowe studentów pedagogiki Uniwersytetu Rzeszowskiego w kontekście miejsca ich zamieszkania. Zarzadzanie Publiczne, 2(46), 171-187. doi: 10.4467/20843968ZP.19.011.10687

Farnicka, M., Liberska, H., (2014). Tworzenie środowiska sprzyjającego uczeniu się - analiza wybranych czynników. Teraźniejszość - Człowiek - Edukacja, 67(3), 57-71.

Janik, A. (2019, 19 lipca). Podkarpacie się wyludnia. Mało się nas rodzi, za dużo migruje. Pozyskano z: https:// plus.nowiny24.pl/podkarpacie-sie-wyludnia-malo-sie-nas-rodzi-za-duzo-migruje/ar/c1-14268967

Kim, Y., Mok, S.Y., Seidel, T. (2020). Parental Influences on Immigrant Students' Achievement-Related Motivation and Achievement: A Meta-Analysis, Educational Research Review, 30.

Kocowski, T., (1993). Motywacja. W: W. Pomykało (red.), Encyklopedia pedagogiczna. Warszawa: Fundacja Innowacja, 384-389.

Mantica, A., Moneva, J., Malbas, M. (2020). Family Status and Self-Motivation in Studies. International Research in Education, 8(1), 124-138. 
Messineo, L., Allegra, M., Seta, L. (2019). Self-reported motivation for choosing nursing studies: a self-determination theory perspective. BMC Medical Education, 19(192). doi: 10.1186/s12909-019-1568-0

Miciura, B. (2020, 15 kwietnia). Szkoła jako środowisko wychowawcze. Pozyskano z: http://www.publikacje.edu.pl/publikacje.php?nr=5836

Nadobnik, J., Tarnowski, M., Nowak, M.A. (2017). Motives for Choosing Studies as Predictors of Career Plans of Tourism and Recreation Students. Central European Journal of Sport Sciences and Medicine, 18(2), 107-118. doi: 10.18276/cej.2017.2-11

Nowak, J. (2015). Środowisko uczące - (nie)doceniony obszar edukacji. Lubelski Rocznik Pedagogiczny, XXXIV(2), 63-75. doi: 10.17951/lrp.2015.34.2.63

Poleszczuk, J. (2017). Decyzje edukacyjne maturzystów. Kontekst społeczny i indywidualne postawy młodzieży Białegostoku wobec wykształcenia wyższego. Pogranicze. Studia Społeczne, XXXI, 1341. doi: 10.15290/pss.2017.31.01

Reykowski, J. (1992). Procesy emocjonalne. Motywacja. Osobowość. W: T. Tomaszewski (red.), Psychologia ogólna. Warszawa: Wydawnictwo Naukowe PWN.

Rozporzadzenie Ministra Edukacji Narodowej z dnia 16 sierpnia 2018 r. w sprawie poradnictwa zawodowego (Dz.U. 2018, poz. 1675).

Tołwińska, B. (2009). Motywacja dzieci do uczenia się (problemy dzieci, rola dorosłych). W: J. Izdebska, J. Szymanowska (red.), Wielowymiarowość przestrzeni życia współczesnego dziecka. Białystok: Trans Humana Wydawnictwo Uniwersyteckie, 195-203.

Zimbardo, P.G., Johnson, R.L., McCann, V. (2010). Psychologia. Kluczowe Koncepcje. Motywacja i uczenie się. Warszawa: Wydawnictwo Naukowe PWN.

Zbigniew Chodkowski, dr nauk humanistycznych w zakresie pedagogiki. Pracuje na stanowisku adiunkta w Katedrze Badań Społecznych Instytutu Pedagogiki w Kolegium Nauk Społecznych Uniwersytetu Rzeszowskiego w Rzeszowie. Prowadził wykłady, ćwiczenia, seminaria licencjackie i magisterskie. Brał dwukrotnie udział w wyjazdach dydaktycznych z programu Erasmus+. Prowadził wykłady ze studentami z programu Erasmus+ z przedmiotów: andragogika i przystosowanie człowieka do środowiska pracy. Założył i prowadzi od maja 2017 r. Studenckie Koło Naukowe Andragogów przy Instytucie Pedagogiki. Zajmuje się następującymi obszarami badawczymi: edukacja, pedagogika pracy, zasoby ludzkie, a także adaptacja człowieka do środowiska pracy. Eksploruje badawczo wszelkie niebezpieczeństwa, które powodują zagrożenia w życiu osobistym i pracy zawodowej człowieka. Prowadził projekty badawcze lub w nich uczestniczył.

Zbigniew Chodkowski, PhD in Pedagogy. He works as an assistant professor at the Chair of Social Research of the Institute of Pedagogy at the College of Social Sciences of the University of Rzeszów in Rzeszów. He conducted lectures, exercises, undergraduate and graduate seminars. He has participated twice in educational trips as part of the Erasmus+ program. He gave lectures to Erasmus+ students in the following subjects: andragogy and human adaptation to the work environment. $\mathrm{He}$ has founded and he runs the Student Andragogues Scientific Circle at the Institute of Pedagogy. He deals with the following research areas: education, work pedagogy, human resources, as well as human adaptation to work environment. In addition, he researches all dangers that can pose threats to personal and professional life. He led and participated in research projects.

ORCID: https://orcid.org/0000-0001-5114-2314

\title{
Adres/Address:
}

\author{
Uniwersytet Rzeszowski \\ Kolegium Nauk Społecznych \\ Instytut Pedagogiki \\ Katedra Badań Społecznych \\ ul. ks. Jałowego 24 \\ 35-010 Rzeszów, Polska \\ e-mail: zchod@ur.edu.pl
}

